\title{
Spatial patterns of fire occurrence in Catalonia, NE, Spain
}

\author{
Ricardo Díaz-Delgado ${ }^{1, *}$, Francisco Lloret $^{1}$ and Xavier Pons ${ }^{1,2}$ \\ ${ }^{1}$ Centre for Ecological and Forestry Applications Research (CREAF), Autonomous University of Barcelona, \\ Bellaterra, 08193, Barcelona, Spain; ${ }^{2}$ Department of Geography, Bellaterra, 08193, Barcelona, Spain; \\ *Author for correspondence (email: rdiaz@ebd.csic.es)
}

Key words: Fire occurrence, Fire recurrence, Fire size distribution, Fractal dimension, Land cover, Lorenz curves, Spots, Residual vegetation islands

\begin{abstract}
In this paper, we analyse spatial patterns of fire occurrence in Catalonia (NE Spain) during 1975-98. Fire scar maps, discriminated by means of 30-60 m resolution remote sensing imagery, have been used as a source of fire occurrence. We employ several visual or analytical approaches to interpret fire occurrence in this region, such as those of Minnich and Chou (1997), Ricotta et al. (2001) or Krummel et al. (1987). Crucial spatial patterns such as fire size distribution, fire frequency distribution, spots and residual vegetation islands are documented. In addition, several geographical layers were overlaid with burned area maps in order to determine interactions between fire occurrence and environmental parameters such as altitude, slope, solar radiation, and burned land cover. Assuming that fire occurrence is well determined by such a posteriori empirical factors we detect areas most prone to fire in this region and aim to enhance the local forest management and conservation plans.
\end{abstract}

\section{Introduction}

Fire is a major agent of spatial pattern formation in plant communities, as it creates a mosaic of burned and unburned patches (Miller and Urban 1999). It is a major disturbance event in several ecosystems, and in the Mediterranean plays a relevant role in determining landscape structure and plant community composition (Trabaud 1994). Several factors may explain fire ignition and occurrence of forest fires, among which fuel characteristics (fuel type, fuel load, fuel moisture and fuel inflammability) are prominent (Rothermel 1972; Rothermel 1983; Albini 1976; Finney 1999). After fire ignition occurs, flames are propagated mainly according to fuel, topography and meteorological conditions (wind, air humidity). When fire suppression practices are carried on, the final fire perimeter is the result of the natural propagation of fire and the fire fighting which attempts to minimise the final burned area.
Quantification of spatial pattern and structure is central to the study of landscape ecology, and Geographic Information Systems (GIS) have greatly contributed to this purpose (Johnston 1990). By analysing spatial fire occurrence we can re-examine which plant communities were the most affected by fire. We can also analyse how fire occurrence is related to topography, climatic parameters, human activity or any other relevant variables definitely involved in fire occurrence (Perry et al. 1999; Donnegan and Rebertus 1999). These variables determine specific spatial patterns which can be analysed by multiscale approaches, such as fractal dimension (D) (Mandelbrot 1977). Krummel et al. (1987) used D values to discern at what scale human pressure was highest over forest patches, i.e., what patch sizes were more regular due to anthropogenic pressure (forest cuttings and agricultural practices). However, no results have been reported on D values for burned areas in relation to previous D values of other landscape elements. 
Spots and residual unburned vegetation islands resulting from fire are landscape elements, which have been poorly studied. Spots are usually generated by fire sparks transported by wind convection as a consequence of extremely hot conditions (Trabaud 1992). These firebrands can initiate a new fire focus very far away from the main fire perimeter. Distance reached by spots is mostly determined by wind speed, mean height of tree cover, altitude difference between the burning area and the closest valley (with lower altitude), and transversal longitude of the valley (Rothermel 1972). Residual vegetation islands are unburned sites within the fire perimeter (Eberhart and Woodard 1987). Several studies have pointed out the relevance of vegetation islands in plant and animal recruitment after fire (Zasada 1971; Gasaway and DuBois 1985). Fire history maps enable detailed analysis of both phenomena by describing variability in number, mean and maximum patch size of both vegetation islands and spots, as well as the maximum distance reached by spots from the main fire perimeter. They can also be used to look for relationships with fire size.

Fire history mapping is the first step in the process of the spatial analysis of fire occurrence in a territory. Global positioning systems (GPS) allow improved georeferencing of the burned/unburned boundaries. After the burned patches are geographically located, they may be overlaid with other relevant information layers. However, this spatial information of fire occurrence at regional scale is not usually available. In Spain, only in the last decade, detailed geographic limits of burned area have been systematically mapped from aerial photography remote sensing imagery. Salvador et al. (2000) developed and validated a semiautomatic method to detect fire scars by using a long time series of Landsat MSS images from 1975 to 1993 . The resulting fire scar map was enlarged by incorporating wildfires occurred between 1994 and 1998 (Díaz-Delgado et al. 2002). The final map covers $>0.3 \mathrm{~km}^{2}$ burned areas along the total period 1975-98 over a region of about $32000 \mathrm{~km}^{2}$ with a high degree of accuracy. Fire recurrence was also determined by spatial overlay of the final pixel resolution $(60 \times 60 \mathrm{~m})$. In this area, there has been a dramatic increase of the number of large fires in the last decades (Moreno et al. 1998). This has been argued to be due to increasing summer drought (Piñol et al. 1998), fuel accumulation as a consequence of land abandonment, changes in fire suppression policies, and more human originated ignitions (Terradas and Piñol 1996).
In this paper we analyse the spatial patterns of fire occurrence in Catalonia (NE Spain) along the last quarter of the $20^{\text {th }}$ century (1975-98). This period has experienced changes in fire suppression and socioeconomic policies. Rural abandonment, which started in the first half of the $20^{\text {th }}$ century, became more evident across the territory at the end of the century (Lloret et al. 2002). Until 1986, fire-fighting tasks were mainly conducted with no specific management plans. In 1986 a special fire prevention and suppression plan named FocVerd I (DARP 1999) was adopted by the regional administration.

Our main aims in this study are (1) to analyse changes in fire size distribution during the study period, (2) to establish the relationship between fire size and the occurrence of spots and unburned vegetation islands, and (3) to identify the socio-environmental variables (vegetation, topography, climate, and human activity) that are determining fire occurrence. More specifically, we hypothesise that (1) the reinforced fire suppression policy is effective at reducing small fires, but not very large ones, increasing fire size inequality across the landscape, (2) there is a positive relationship between fire size and spot and unburned vegetation occurrence, and (3) larger fires are associated with Mediterranean-type climate and vegetation. We extract the spatial pattern fire parameters (Minnich and Chou 1997; Ricotta et al. 2001; Krummel et al. 1987) by analysing data from burned area maps obtained from remote sensing images and incorporated into a vector GIS layer.

\section{Study area}

The Catalonia region includes an area of 32,100 km² in the northeastern Iberian Peninsula, near the Mediterranean Sea (Figure 1). Approximately 60\% is covered by shrubland and forests but a dense human population has led to fragmentation of vegetation. Although there are mountains as high as 1500-3000 $\mathrm{m}$ with cold winters, the majority of the study area has a Mediterranean climate, with winter precipitation and summer drought (Terradas and Piñol 1996). According to the First Ecological Forest Inventory of Catalonia (Gracia et al. 1997), current forests include 20\% Pinus sylvestris, 20\% Pinus halepensis, 16.6\% Quercus ilex, 12.5\% Pinus nigra, 5.5\% Quercus suber, 4.8\% Pinus uncinata, and 4.0\% Quercus humilis, and 3.3\% Pinus pinea. Species such as Abies alba, Castanea sativa, Fagus sylvatica, Pinus pinas- 


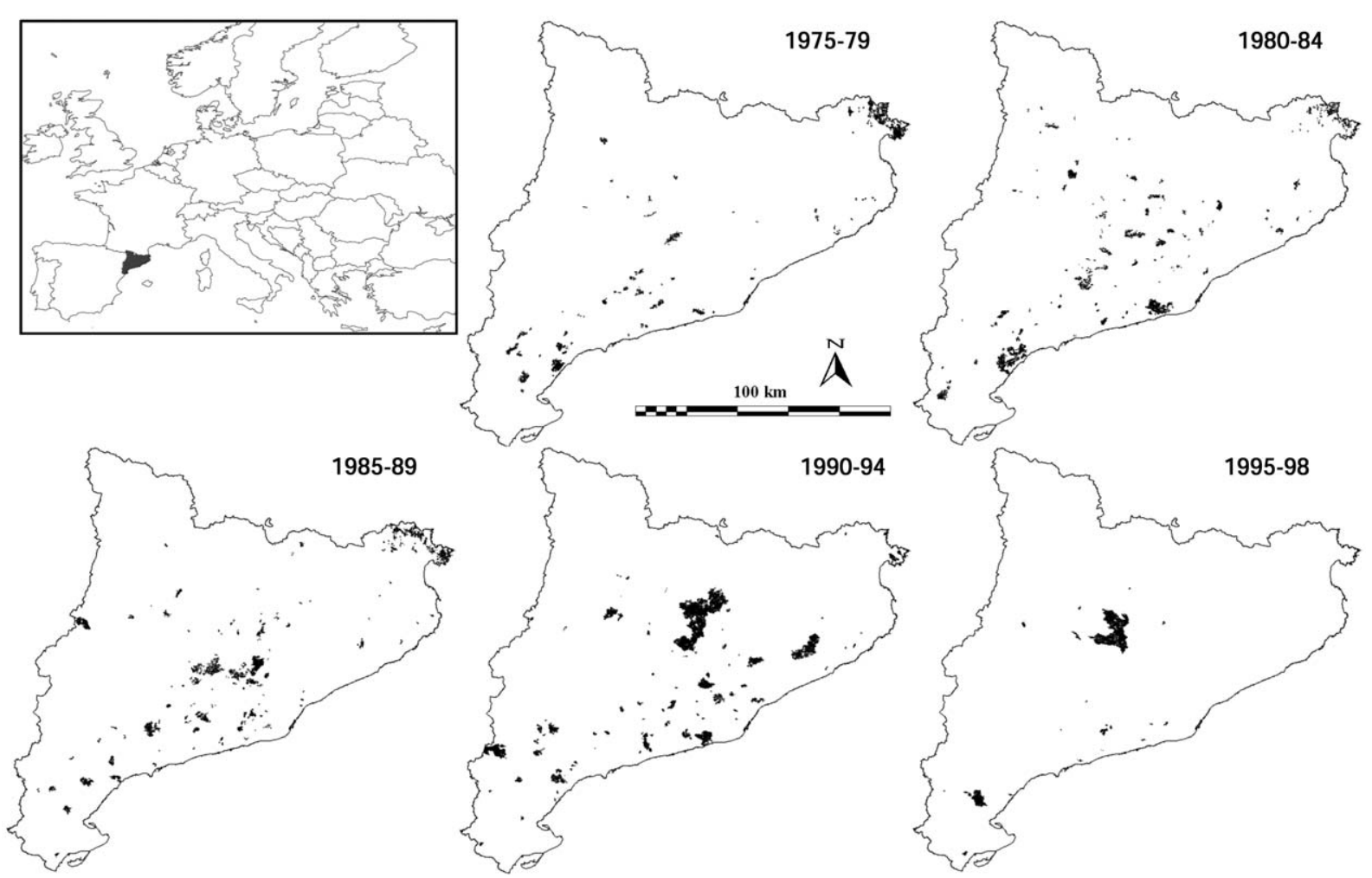

Figure 1. Location of Catalonia in the European context and burned areas (in black) detected by remote sensing for every five-year periods in the last 24 years.

ter and Quercus cerrioides occupy between 1\% and $3 \%$ of the area. Evergreen species (31 species) occur in $86 \%$ of the total forested area (of which $73 \%$ of the area is occupied by conifers), while deciduous trees (58 species) cover the $14 \%$. According to the CORINE (1991) land cover map, shrublands cover 26.6\% of the total wildland area (1 $950326 \mathrm{ha}$ ), with a diverse specific (and mainly evergreen) composition (Folch 1986). The CORINE land cover categories in this study include:

- Class 3: forests and semi-natural areas, with the exception of subclasses; 3.3.1: Beaches, dunes, sand; 3.3.2: Bare rocks; and 3.3.5: Glacier and permanent snow fields.

- Class 2: agricultural areas. Only the subclass 2.4.3: Land principally occupied by agriculture, with significant areas of natural vegetation.

\section{Methods}

Following the procedure developed by Salvador et al. (2000), landscape fire scars greater than $0.3 \mathrm{~km}^{2}$ were mapped by subtracting consecutive NDVI images of Landsat MSS with values greater than variable threshold values. The NDVI is a vegetation index calculated from the ratio between pixel reflectances on the near infrared and red bands. It maximises the spectral vegetation response by showing high values in areas with dense vegetation cover. Therefore, subtraction of consecutive temporal images will yield negative values of large magnitudes for burned areas. Thresholds were obtained from empirical regression models based on 21 fires (Salvador et al. 2000). This procedure also allows recognition of areas that have burned more than once during the study period. Therefore, fire scar maps obtained were converted from raster to vector GIS structured format to enable spatial analysis and query of the database. For every fire, we determined a date of fire and other relevant fire attributes, such as burned area and fire perimeter. Wells and McKinsey (1990) showed that the effi- 
ciency in the information storage and accessibility of data is better in raster format, helping forest fire management in southern California. However, we used vector format due to its structural hierarchy (Maffini 1987; Minnich and Chou 1997). The vector format of our fire database allows the analysis of occurrences (number of fires along the period) in any geographical point by multiple records (the same element is linked to several registers, Date 1995).

The ancillary maps used to complete the fire history database were the Forest Fire Map of Catalonia (1986-1990); CORINE Land-Use-Land-Cover map (1991) and the Land Use Cover Maps of Catalonia from 1987 and 1992. They record 14, 3, 3 and 10 fire scars respectively that were not detected by our methodology (30 new scars from a total of 445). Data on burned areas larger than $0.5 \mathrm{~km}^{2}$ that occurred between 1994 and 1998 were kindly provided by the Department of Environment of local government (Generalitat de Catalunya), adding 24 fires to the fire history from 1975 to 1998.

\section{Spatial patterns}

The fire history database includes a total of 445 fires larger than $0.3 \mathrm{~km}^{2}$. As graphic elements, they are linked to an attribute table where ancillary data is stored. This table includes fire date, year, dates of images pre- and post-fire, the most affected municipality together with its code, number of spots, maximum distance reached by spots, other municipalities affected by fire and the nature of vegetation prior to fire, obtained by photointerpretation in the late 70's from Mapa de Cultivos y Aprovechamientos (MCA) (MAPA 1980a) and Mapa Forestal de Catalunya (MFC) (DARP 1996). Vegetation maps consisted of land cover groups. The five final vegetation groups were: broad-leaved forest, conifer forest, shrubland, grassland (natural and pastures) and crops.

Standard layer overlay techniques were applied to analyse interactions between fire occurrence and the other variables. This cross-tabulation process enables the retention of all the attributes linked to each graphic element. Logical query was then employed to yield preliminary statistics. Finally, metric distances were measured on-screen. Lorenz curves (see below) were also applied to dominant land cover.
Fire size

Four different visual approaches were used to analyse fire size distribution:

- Standard representation of number of fires vs. fire size (Fire Size Frequency distributions).

- Lorenz curves, which show adequately the "concentration”, "evenness” or "inequality” of any continuous variable (Lorenz 1905; Rousseau et al. 1999). The percentage of total burned area is depicted vs. percentage of the number of fires of increasing size. The Gini coefficient (Lee and Seyoung 1998) allows the estimation of inequality. It varies between 0 (maximum equality) and 1 (maximum inequality) (Weiner and Thomas 1986; Bendel et al. 1989; Lieffers and Titus 1989).

- An estimate of "self-organised critical behaviour" employed by Malamud et al. (1998), Ricotta et al. (1999) and Ricotta et al. (2001). The distribution of number of fires exhibits a potential (fractal) relationship with the minimum fire size as:

$$
\mathrm{Nf} / \mathrm{Ns}=\mathrm{f}\left(\mathrm{A}_{\mathrm{F}}^{-\mathrm{a}}\right)
$$

where $N_{F}$ is the number of fires with a size equal to or larger than $A_{F}$ along the study period, $N_{S}$ is the number of years analysed, $A_{F}$ is fire size and a is the slope of the fitted linear model to the relationship between $\log \left(\mathrm{N}_{\mathrm{F}} / \mathrm{N}_{\mathrm{S}}\right)$ and $\log \mathrm{A}_{\mathrm{F}}$. When a $>1$ small fires highly contribute to the total area burned. When $\mathrm{a}<1$ large fires are the ones determining the most of the total area burned. This method allows the comparison of spatial pattern between different fire regimes, and the fire size range contributing to total burned area. Cumulative frequency-area distributions allow the prediction of maximum expected fire size. However, the use of power-law relationships of fire size requires that both the small and large fires be removed, since the power law function works only for intermediate sized fires at best (Reed and McKelvey 2002).

- The database was divided into five-year intervals to check the relationship between fire management policies and fire size (Figure 1). We compared fire size distributions obtained in Catalonia to fire size distributions in southern California, where there is debate about the effect of fire suppression policies 
on the size of burned areas (Minnich and Chou 1997; Keeley and Fotheringham 2001; Keeley et al. 1999).

\section{Spots and vegetation islands}

For each fire we also evaluated the relationship between fire size, the number of spots, the maximum distance reached by fire spots from the main perimeter, and the number of vegetation islands. In all the cases simple linear regression models and $r^{2}$ coefficient of determination were applied after normalisation of data. One-way ANOVA was applied to search for differences in these variables per five-year intervals. Only fires with spots were included in these analyses.

\section{Analytical spatial layer cross-tabulation of socio-environmenatl variables}

Fire scars, vegetation and other thematic maps were spatially overlaid to identify co-occurrences among them. Continuous variables such as altitude (Digital Elevation Model) were converted in categorical rank before proceeding with the spatial overlay. We calculated a percentage of the total burned area versus the total available surface covered by every class of the following variables:

- Vegetation: We examined percentages of every burned vegetation group as a function of the respective total area covered at the early times of the study period. We extracted each land cover area from the First Forest National Inventory (IFN) (only broad-leaved and conifer forest information, MAPA 1979; MAPA 1980b) as well as from the land use cover map from the end of 70's (MCA, MAPA 1980a). This map is the oldest cartography identifying the dominant vegetation cover before all the fires analysed at a relatively detailed scale.

- Topography (Digital Elevation Model): A DEM with spatial resolution of $45 \mathrm{~m}$ (ICC-DARP 1993) was reclassified in 16 equal-size classes. Slope, extracted from the DEM, was similarly reclassified into 12 classes.

- Climate: Mean annual rainfall, mean annual temperature, mean annual evapotranspiration and thermal amplitude (the range of the maximum temperature from winter to summer) were obtained from the Climatic Atlas of Catalonia (ICC 1997). Solar radiation was cross-tabulated from the model of Pons (1996).

- Socio-economic variables: Land ownership as public or private (DMA 2001) as well as protection status (i.e., natural parks and reserves) were included in the analysis.

\section{Fractal dimension}

Fractal dimension (D) was used to interpret landscape structure (Nikora et al. 1999). D is calculated from the following area-perimeter relationship:

$$
P=A^{D}
$$

Or, similarly as,

$$
\log \mathrm{P}=1 / 2 \mathrm{D} * \log \mathrm{A}
$$

where $\mathrm{P}$ and $\mathrm{A}$ are the fire perimeter and area respectively, and D, fractal dimension, describes the level of irregularity of the landscape elements analysed.

Here, we employed the slope method (Lovejoy 1982), by which D is estimated from linear regression on a $\log / \log$ representation of perimeter elements vs. the subtended areas. D values are assumed to be the slope of the linear model fitted to the perimeter and size of burned and forest patches (tree cover $>$ $20 \%)$. Spots were considered separately as single fires, and assume that their spatial pattern is determined by the pattern of the vegetation patches where they took place. A total amount of 2,862 burned patches were analysed. D was also calculated for dense tree cover patches $(60,255$ patches), in order to compare the fractal dimension of unburned tree cover patches and burned patches.

\section{Results}

\section{Fire size distribution}

Forest fires larger than $0.3 \mathrm{~km}^{2}$ burned $2340 \mathrm{~km}^{2}$ in Catalonia. About $300 \mathrm{~km}^{2}$ (13\%) had reburned (Table 1). We estimate that the Natural Fire Rotation period was about 133 years (NFR = Number of years in period / (Total area burned over period / Size of study area), Heinselman, 1973). The mean fire size for the 
Table 1. Total burned area $\left(\mathrm{km}^{2}\right)$ per recurrence level in Catalonia and percentages of area burned once, study area and forest area (fires larger than $0.3 \mathrm{~km}^{2}$ along 1975-98).

\begin{tabular}{|c|c|c|c|c|}
\hline Recurrence & Burned area (\%) & Percent of area burned once & Percent of study area & Percent of forest area \\
\hline Once & $2041.78(87.18 \%)$ & - & 12.20 & 10.47 \\
\hline Twice & $271.21(11.58 \%)$ & 13.28 & 1.62 & 1.39 \\
\hline Three times & $23.78(1.01 \%)$ & 1.16 & 0.14 & 0.12 \\
\hline Four times & $3.16(0.13 \%)$ & 0.15 & 0.02 & 0.02 \\
\hline Five times & $1.60(0.06 \%)$ & 0.08 & 0.01 & $<0.01$ \\
\hline Six times & $0.43(0.01 \%)$ & 0.02 & $<0.01$ & $<0.01$ \\
\hline Total & $2341.95(100 \%)$ & 14.70 & 13.99 & 12.01 \\
\hline
\end{tabular}

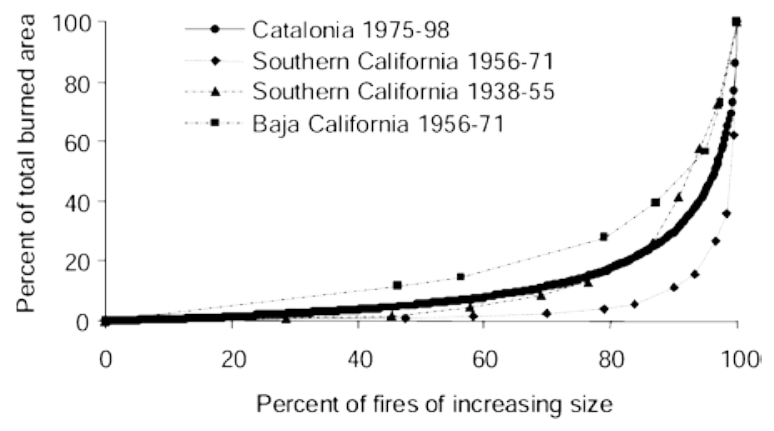

Figure 2. Lorenz curves of fire size distribution in Catalonia, (1975-98), Southern California (1938-55 and 1956-71) and Baja California (1956-71) from Minnich and Chou (1997). Eccentricity denotes a major contribution of large fires to total burned area.

entire period was $6.22 \mathrm{~km}^{2}$, while the median is 1.23 $\mathrm{km}^{2}$, and modal size is $0.54 \mathrm{~km}^{2}(\mathrm{n}=445)$.

The Lorenz curve for Catalonia (1975-98) (Figure 2) is similar to the southern California curve in 1938-55 and intermediate between the Baja California in 1956-71 and the southern California curve in 1956-71 (data from Minnich and Chou 1997). The respective Gini coefficients (0.77 for Catalonia, 0.74 for southern California in 1938-55, 0.91 for southern California in 1956-71, and 0.61 for Baja California in 1956-71) indicate that the lowest degree of inequality is observed in Baja California, being the values of Catalonia similar to the existing in southern California in the 1938-55 period.

Fire size frequency distributions at five-year intervals indicate that the number of fires overall has decreased, but fire size inequality, i.e., the number of large fires, has increased through the study period (Figure 3, Figure 4; Table 2). Table 2 also shows the dramatic increase of mean fire size.

The Nf/Ns model adjusted to a logarithmic function $\left(\mathrm{r}^{2}=0.82, \mathrm{p}<0.01, \mathrm{n}=445\right)$ does not predict the behaviour of the extremes (small and large fires, Figure 5). Here we locate the cut-offs that break off

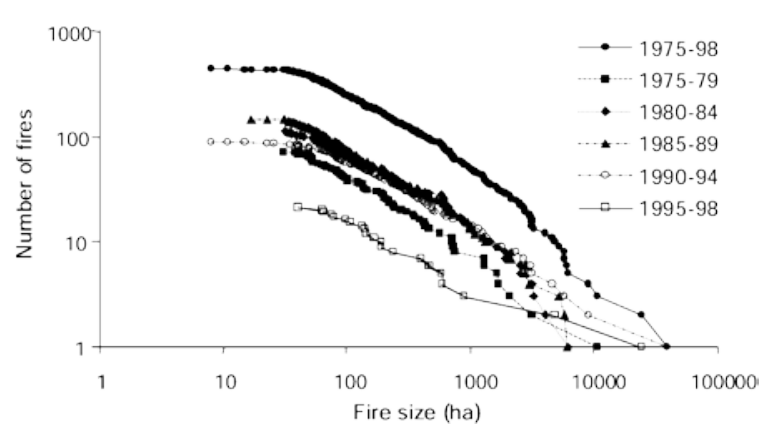

Figure 3. Fire size distribution for every five-year intervals and the whole period (1975-98).

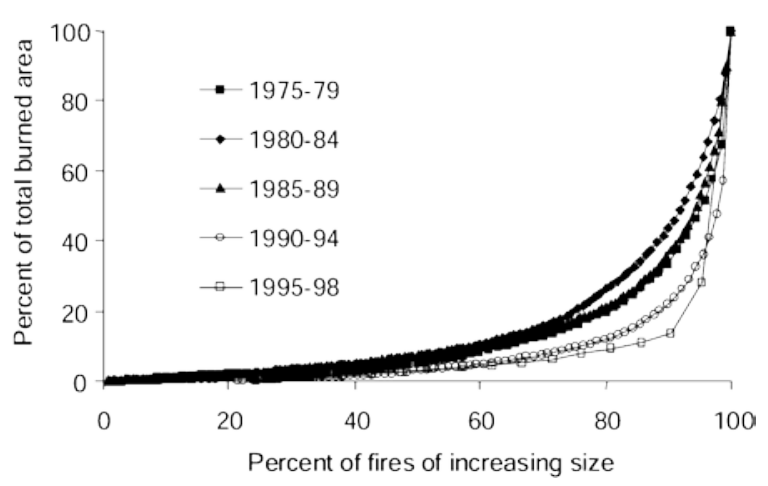

Figure 4. Lorenz curves of fire size per five-year intervals in Catalonia. The two last periods are the largest contributors to total burned area.

the slope ( $\mathrm{a}=0.72$ ) (Ricotta et al. 1999; Ricotta et al. 2001). It is outstanding the 3 orders of fire magnitude illustrating the adequacy of the method only for intermediate fire sizes (Reed and McKelvey 2002). The predicted value of the intercept with the $\mathrm{X}$-axis estimated by the total model, i.e., maximum expected fire size, is about $10000 \mathrm{~km}^{2}$ (Figure 5) if fire frequency in the last quarter of the century remains constant in the future (445 fires in 24 years). The model fitted to the smaller magnitude gives a 
Table 2. Gini coefficients estimated for five-year intervals within the study period in Catalonia. Average fire size (ha) and number of fires are also shown for every period.

\begin{tabular}{llcr}
\hline Five-year intervals & Gini Coefficient & Av. Fire size & Av. No. of fires \\
\hline $1975-79$ & 0.76 & 478.08 & 70 \\
$1980-84$ & 0.69 & 479.82 & 110 \\
$1985-89$ & 0.72 & 404.17 & 146 \\
$1990-94$ & 0.84 & 1035.08 & 89 \\
$1995-98$ & 0.85 & 1605.20 & 21 \\
\hline
\end{tabular}

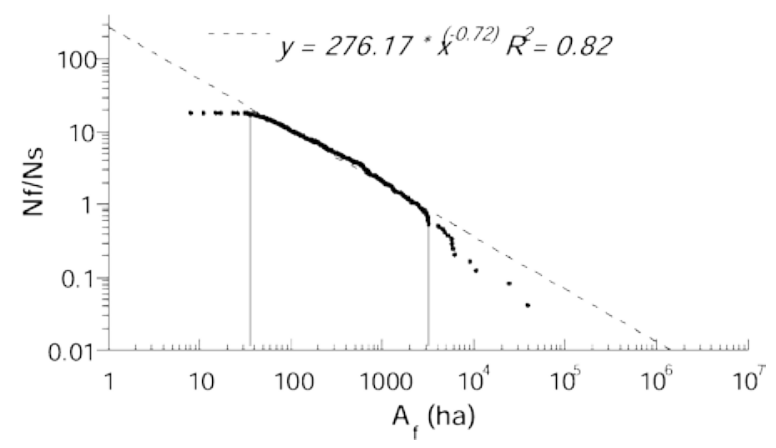

Figure 5. Cumulative frequency-area distribution for Catalonia (1975-98) and total adjusted model. Number of fires $N(>S)$ with size greater than $\mathrm{S}$ is plotted as a function of $\mathrm{S}$ in a log-log space. Notice the unsuitability of the model at both extremes of the distribution.

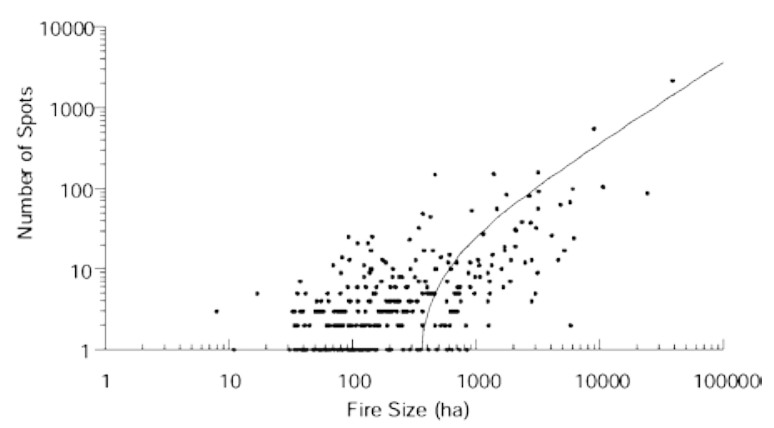

Figure 6. Relationship between the number of spots and fire size in Catalonia (1975-98). Larger fires initiate more spots around the main fire perimeter.

predicted value of $260 \mathrm{~km}^{2}$, which is close to current fire sizes.

\section{Spots and vegetation islands}

Figure 6 shows a strong relationship between fire size and the number of spots for each fire $\left(\mathrm{r}^{2}=0.68\right.$, $\mathrm{p}$ $<0.01, \mathrm{n}=304)$. However, the maximum distance of spots from the main fire perimeter shows a signif- icant but weak correlation $\left(\mathrm{r}^{2}=0.06, \mathrm{p}<0.01, \mathrm{n}=\right.$ 304).

The number of fires with no spots was 141 (31\%). Ninety-one \% of spots appear linked to smaller fire size classes $\left(0.35\right.$ and $\left.5 \mathrm{~km}^{2}\right)$. Eighteen out of hundred of total burned area is attributed to spot fires. This percentage increases with fire size, from the $18.5 \%$ for fires of $0.35-2 \mathrm{~km}^{2}$ to $27.1 \%$ for fires of $50-400 \mathrm{~km}^{2}$.

The number of spots have increased over time (One-way ANOVA, $\mathrm{p}<0.05, \mathrm{~F}=2.83, \mathrm{r}^{2}=0.25$, $\mathrm{p}<0.01$ ), but no correlation was found between the maximum distance of spots and fire size.

A significant correlation was found between fire size and number of vegetation islands $\left(\mathrm{r}^{2}=0.80\right.$, $\mathrm{p}$ $<0.01, \mathrm{n}=244)$, as well as between fire size and the size of vegetation islands $\left(\mathrm{r}^{2}=0.90, \mathrm{p}<0.01\right.$, $\mathrm{n}$ $=244$, Figure 7 ). Forty-five $\%$ of fires are compact patches with no residual vegetation islands. However, $95 \%$ are found in the smaller fire size class $(0.35-2$ $\mathrm{km}^{2}$ ).

\section{Vegetation cross-tabulation}

Figure 8 shows the total burned area in Catalonia for every year of the studied period. The relative percent of the total burned area by vegetation group shows that conifer forests were the most affected by fire (43\%). Pine woodlands dominated by $P$. halepensis (25\%), P. nigra (14\%) and P. sylvestris (2\%), account for the $95 \%$ of the burned conifer forests. Pine forests are followed by shrublands (31\%), broad-leaved forests (7\%), and grasslands (3\%). Such fires accounted for the $96 \%$ of the total burned area. Relative percent estimated as a function of the respective total area covered at the early times of the study period is shown in Table 3 .

Vegetation types showed different patterns of fire size distributions and Lorenz curves (Figure 9, Figure 10). Conifer forests and shrublands were affected by the largest fires, while small fires were associated 


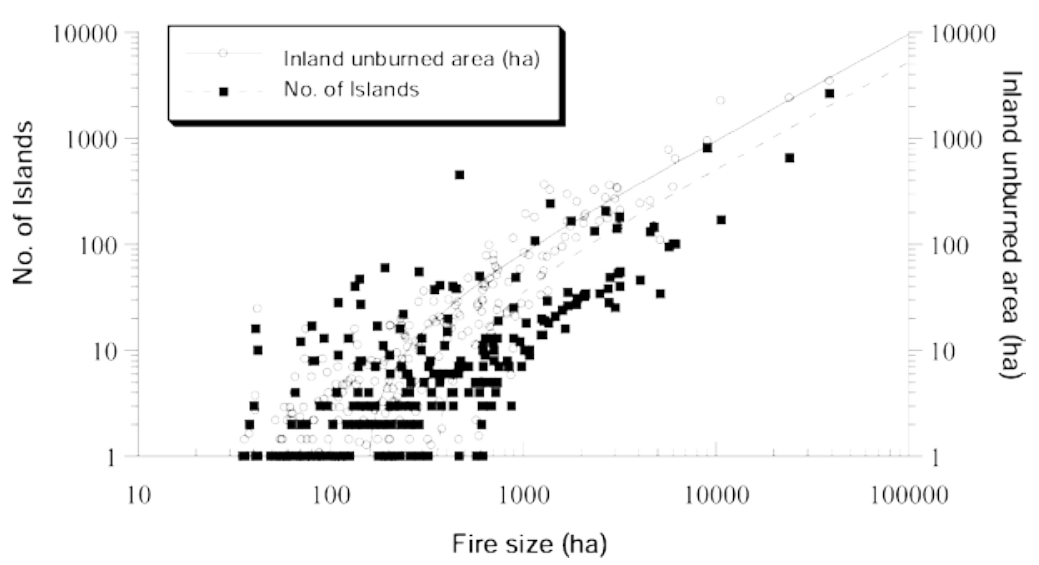

Figure 7. Number and total area of vegetation islands against fires size between 1975 and 1998. Unburned islands and their surface increase as total fire size does.

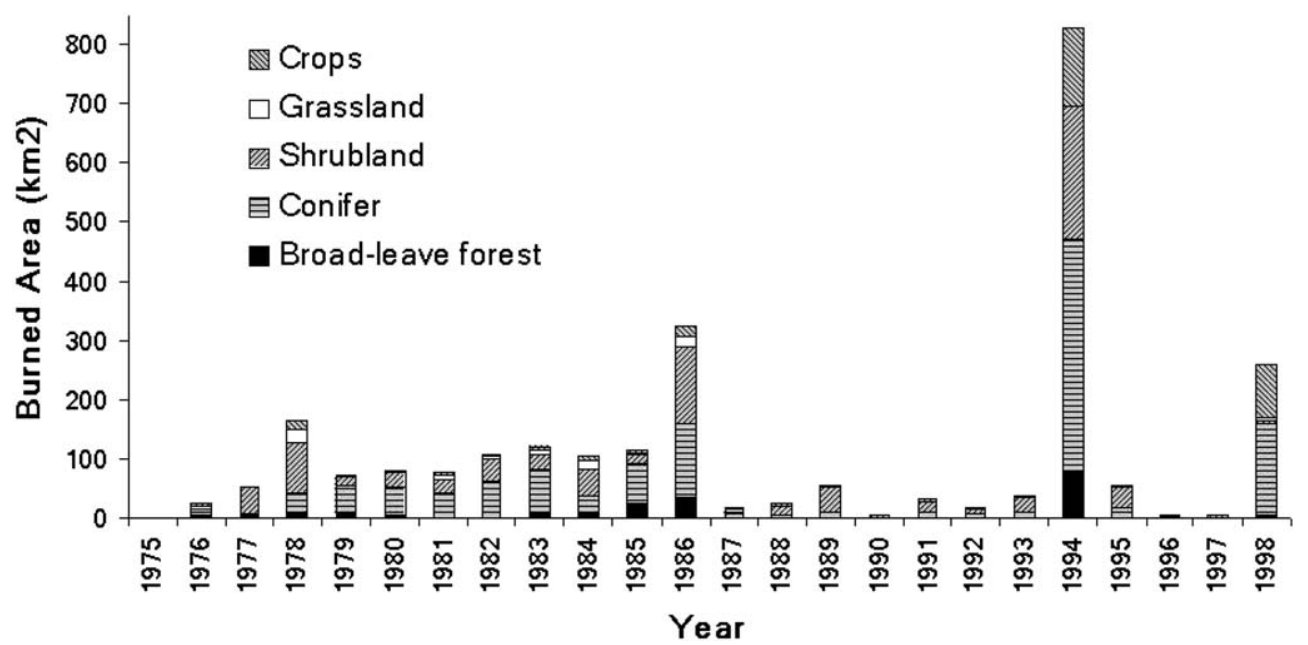

Figure 8. Annual burned area in Catalonia by land cover groups (1975-1998). In 1994 about $850 \mathrm{~km}^{2}$ burned across the territory.

Table 3. Total burned area of every vegetation group in the 1975-98 period and relative percentages to MCA available areas and to IFN (see text for more details).

\begin{tabular}{lccc}
\hline & Total $\left(\mathrm{km}^{2}\right)$ & Relative \% to MCA & Relative \% to IFN \\
\hline Broad-leaved forest & 191.43 & 5.05 & 8.2 \\
Conifer forest & 1154.44 & 13.41 & 2.3 \\
Shrubland & 832.57 & 22.93 & - \\
Grassland & 85.88 & 3.04 & - \\
Crops & 319.49 & 3.17 & - \\
\hline
\end{tabular}

with grasslands and broad-leaved forests (Figure 10). Lorenz curves show small differences between conifer and shrubland fires. Large fires contribute strongly to the total burned area of conifer forest and broadleaf forests, but weakly to burned grasslands. The size of shrubland fires is more evenly distributed, i.e., the occurrence of small and large fires is similar (Figure 10).

\section{Topographic and climatic cross-tabulation}

Altitude: Areas below 1,000 m accounted almost for the total burned area (Figure 11a). 35\% of the surface 


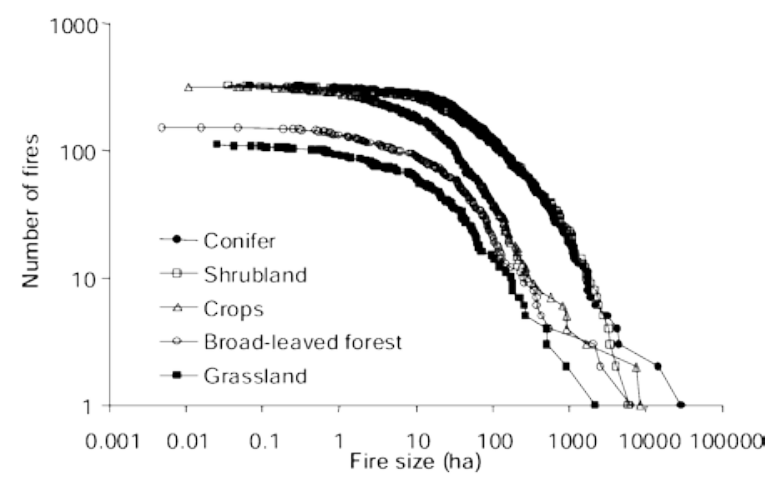

Figure 9. Fire size distribution per land cover group. Most of the conifer and shrubland fires are large fires.

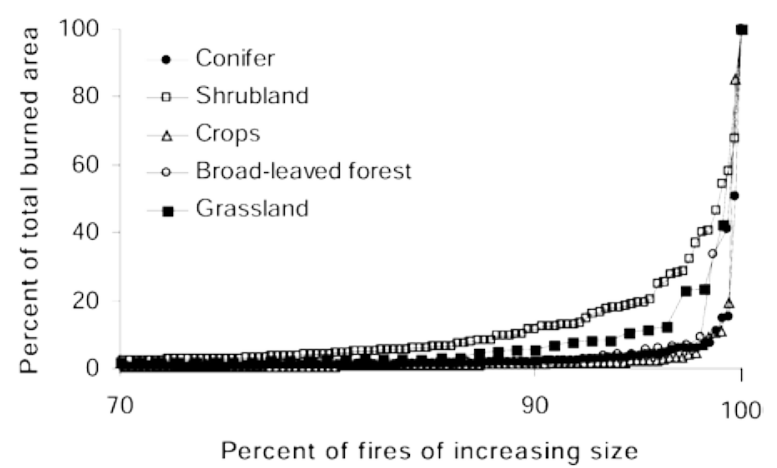

Figure 10. Lorenz curves of fire size per land cover group in Catalonia (1975-98). X-axis has been scaled-up to improve visualisation. Total conifer burned area is mostly consumed by large fires, but burned shrubland is most evenly distributed.

available at this altitude was completely burned. Urban areas are mostly located below this altitude (98\%).

Slope: Slopes steeper than $20 \%$ are more prone to burn than expected in relation to its relative frequency in the territory (Figure 11b).

Climate: Fourteen percent of the total burned area occurred in the territories with highest solar radiation levels (14\% of, Figure 11c). There is a peak of fire occurrence at medium ranks of mean annual precipitation (550-700 mm). However, fire occurrence in localities with low rainfall is lower than expected in relation to the relative frequency of these localities in the territory (Figure 12a). Fires were more prone to occur in localities with mean annual temperatures ranging from 11 and $15^{\circ} \mathrm{C}$ (Figure 12b).

\section{Socio-economical cross-tabulation}

Almost $90 \%$ of the study area belongs to private owners. However, forest public land (8\%) burned more than private land (3\%). Natural reserves burned more ( $10 \%$ of their surface) than non-protected lands (3\% of the surface). Overall $24 \%$ of the burned area in the territory belonged to natural reserves.

\section{Fractal dimension}

$\mathrm{D}$ value for all the fire patches is 1.49 and for all the forest unburned patches is 1.26. Significant statistical differences were found between fire and forest fractal dimension (t-test for independent samples, $\mathrm{t}=41.39$, $\mathrm{p}<0.01)$. In both cases $\mathrm{D}$ values increased with patch size. Patches were much more irregular with increasing perimeter length (Figure 13). While forest patches show a regular and progressive increase of D values with size, fire patches display abrupt changes. The high $\mathrm{D}$ values obtained for large patch size of both fire and forest patches are similar. Table 4 displays patch size variability of both landscape elements.

\section{Discussion}

In Mediterranean-type ecosystems, fire is a common disturbance, and vegetation is able to regenerate rapidly, recovering structure and composition after burning (Hanes 1971; Trabaud 1994). However, limits to this high resilience ability are being identified at different levels, from population (Zedler et al. 1983; Lloret et al. 2003) to landscape (Díaz-Delgado et al. 2002) in relation to several properties of the fire regime associated to spatial patterns, such as extent, frequency, and severity (Eberhart and Woodard 1987; Díaz-Delgado et al. 2002, Díaz-Delgado et al. 2003). Therefore, the analysis of fire occurrence patterns at landscape level is an essential step to identify those areas more prone to experience a dramatic loss of their ecosystem resilience ability as a consequence of changes in fire regime.

Large infrequent fires play the most important role in the total burned area in Catalonia. Between 1975 and 1998 , only the $6 \%$ of the fires larger than $0.3 \mathrm{~km}^{2}$ were larger than $20 \mathrm{~km}^{2}$, but they represent $61 \%$ of the total burned area. These results agree with data obtained from the regional administrative record by Piñol et al. (1998). This pattern is similar to that ob- 


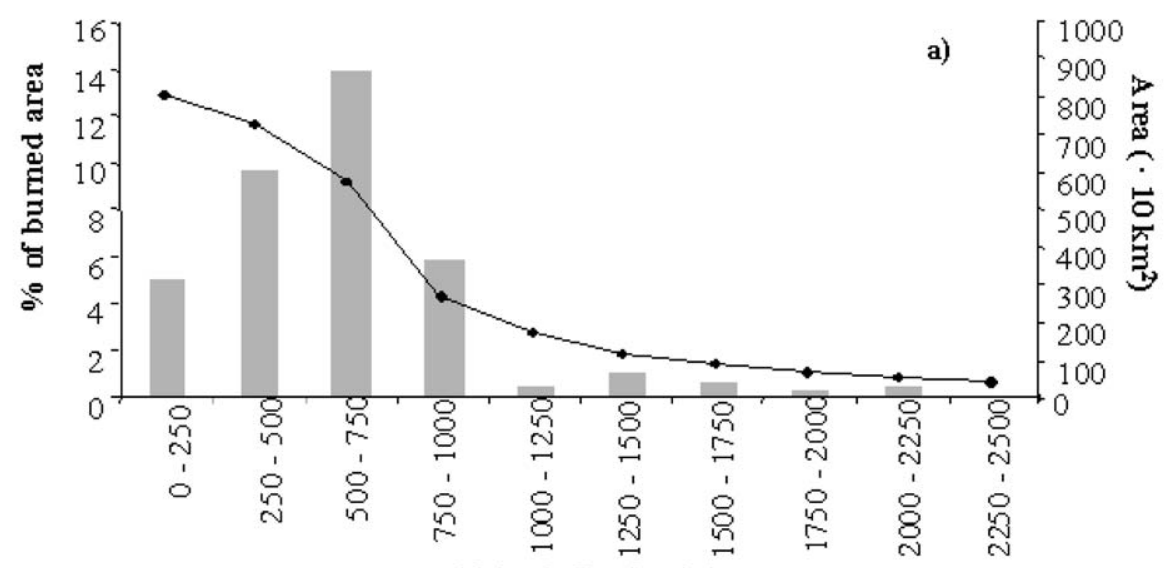

Altitude Ranks (m)
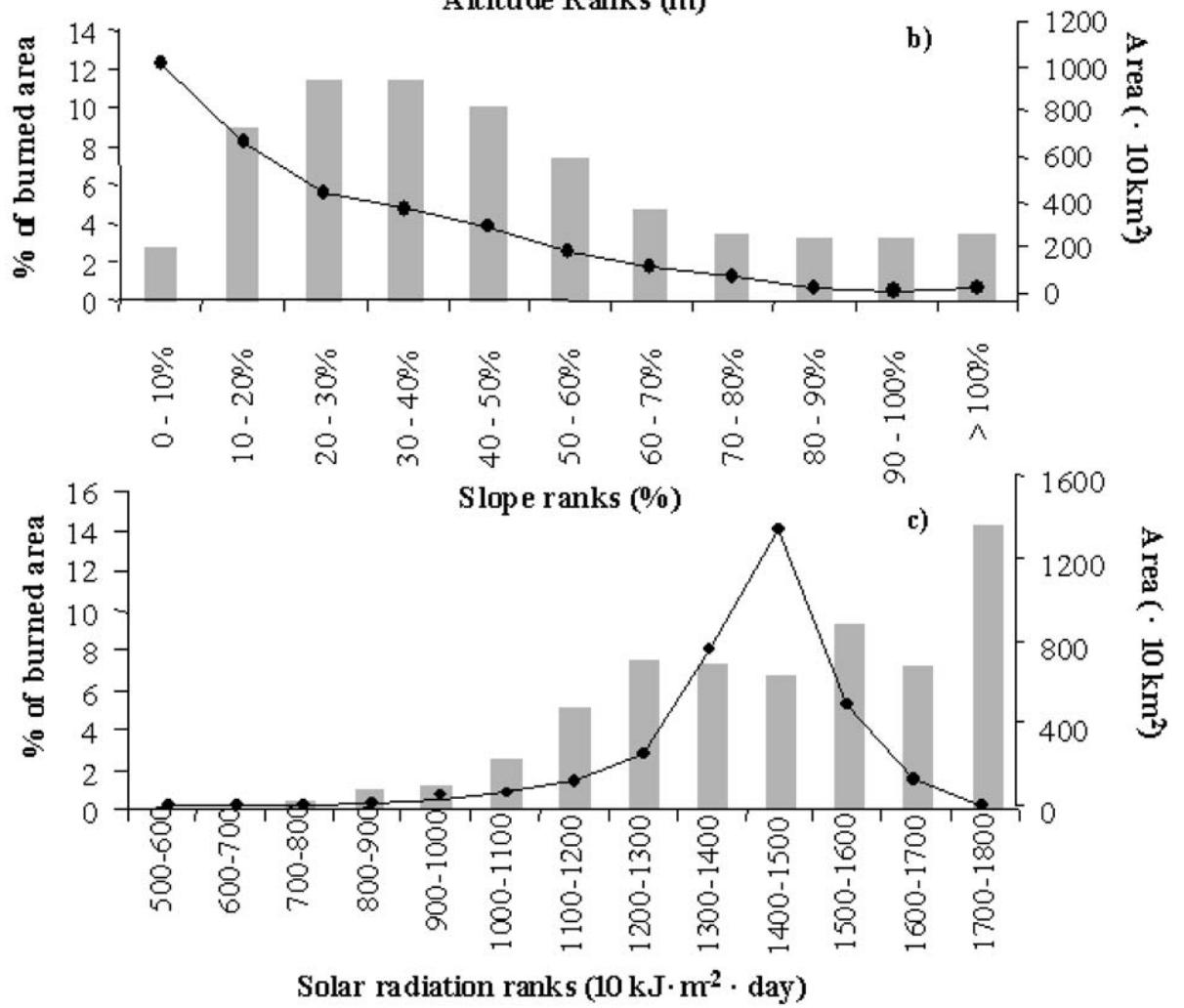

Figure 11. Percent of burn area versus a) altitude b) slope and c) solar radiation. Black lines show the proportion of every variable rank in the study area. Bars in grey-levels indicate fire recurrence.

served in southern California along the 1938-55 period. However, in southern California large fires have increased their contribution to the total burned area in more recent times (1956-71), while the contribution of small fires is higher in Baja California, where no active fire suppression policy is performed (Minnich and Chou 1997).
Fire suppression funds have been increased by 6-fold since the early 80's. This fire management policy was reinforced with fire prevention programs after the disastrous fires in 1994 when more than 1000 $\mathrm{km}^{2}$ burned in Catalonia during a 3-year drought. After the Focverd I suppression plan was fully implemented in 1986, the number of fires was dramatically reduced, but the percentage of large fires increased. 


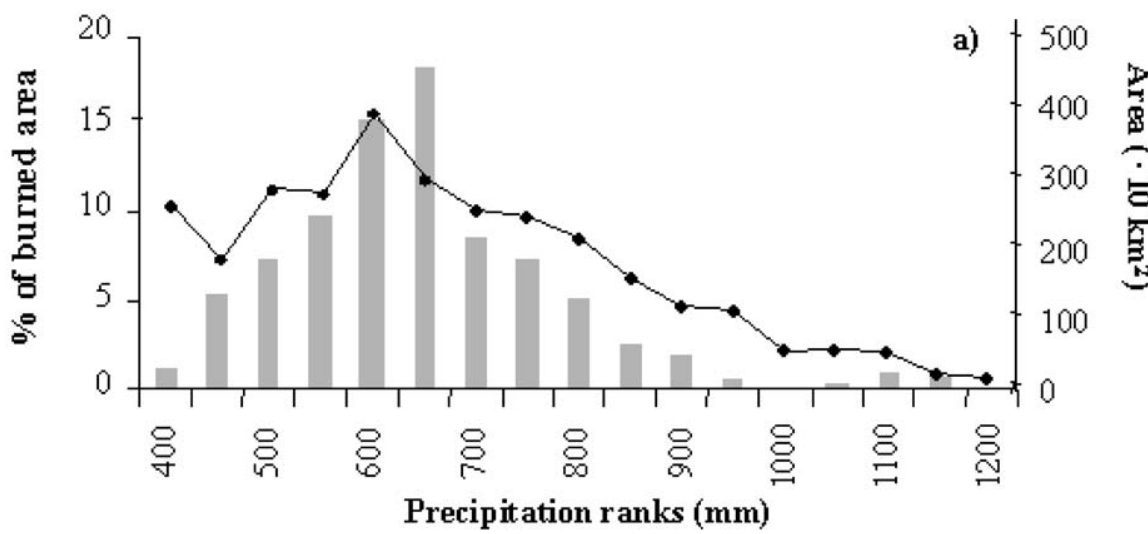

点

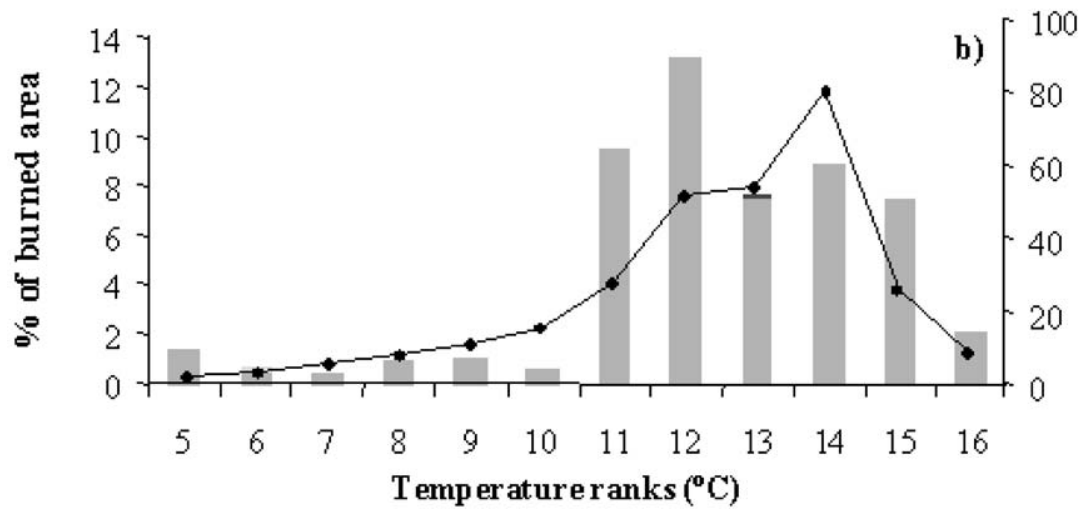

点

Figure 12. Percent of burned area versus a) mean annual rainfall and b) mean annual temperature. Black lines show the proportion of every variable rank in the study area. Bars in grey-levels indicate fire recurrence.

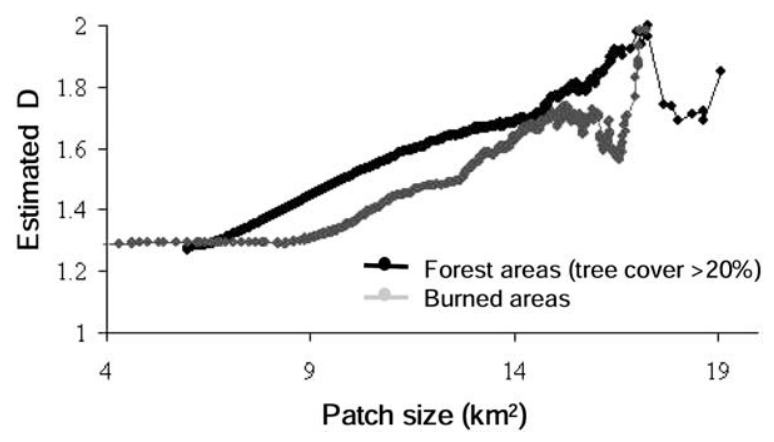

Figure 13. Fractal dimension (D) in relation to patch size both for burned areas and dense forest patches. D was estimated according to the slope method as described in Lovejoy (1982). Changes in slope are attributed to critical sizes revealing underlying patch to patch relationships.

The top $10 \%$ of fires burned an $86 \%$ of total burned area. Gini coefficients of fire size distributions also increased, indicating increasing inequality of fire burned patches in the landscape. In Spain, effective fire suppression started to become intensive in 1960's, coinciding with a period of rural abandonment. Along
Table 4. Descriptive size parameters for fires and dense forest patches $\left(\mathrm{km}^{2}\right)$.

\begin{tabular}{lcc}
\hline & Fire patches & Dense forest patches \\
\hline Median & 0.270 & 0.495 \\
Mode & 0.090 & 0.100 \\
Mean & 0.965 & 0.603 \\
Maximum & 38.44 & 111.13 \\
Minimum & 0.005 & 0.039 \\
Total Number & 2862 & 60255 \\
\hline
\end{tabular}

the 20th century, the meteorological conditions promoting high fire risk (high temperature, low air humidity) have also became more frequent (Piñol et al. 1998). Thus, fuel reduction management alone does not seem enough to avoid large fires. However, according to the observed regional variability in fire size distribution, suppression should be combined with fuel management (Strauss et al. 1989), being this practice more effective when applied in specific, firesensitive locations.

The estimated fire rotation period of 133 years is long especially for Mediterranean ecosystems. The 
study area also included agricultural areas and many of them may not be able to burn. Although the fire history database did not consider fires smaller than $0.3 \mathrm{~km}^{2}$, they do not cause a large cumulative burned area. A study of the administrative records for the 1983-97 period showed that $95 \%$ of fires were smaller than this size, but they only contributed to $7 \%$ of the total burned area. A recent analysis of temporal patterns of the same database (Díaz-Delgado et al. in press) following the mean fire interval method (Arno and Sneck 1977; Kilgore and Taylor 1979; Agee 1993) gives a fire cycle between 23 and 42 years, in agreement with other estimations for similar study areas in Mediterranean-type ecosystems (Agee 1993).

The estimated slope values of the fire frequency distributions (0.72) indicate the importance of large fires in total burned area. When we analysed local administration records (1983-97), which include smaller fires (more than $0.01 \mathrm{~km}^{2}$ ), we obtained a slope value of 0.36 . However, we were unable to fit a linear model across the full range of fire sizes. Ricotta et al. (1999) argues that other factors, mostly exogenous, may be conditioning the lack of fit at extreme intervals. One factor is the efficiency of the fire suppression practice on small fires, enhancing the homogenisation of fuels across the landscape, which can promote large fires (Ricotta et al. 1999).

There is a strong relationship between fire size and the number of spots per fire. A weak but significant relationship was found between fire size and spot distance from the primary fire perimeter. These results appear to support the relationship between fire size and fire intensity. The greater the emitted energy by the fire front, the higher the convection column able to transport incandescent brands (bark fragments, pine cones), and therefore the longer the distance of spots. The number of spots will be higher in more intense forest fires, which in most cases are crown wildfires (Whelan 1995). The changes along the considered period would suggest that there has been an increase in fire intensity. The maximum spotting distances, however, seems less related to fire size and no differences were observed over time.

Residual vegetation islands appear to be produced for a variety of reasons such as differences in edaphic water content (Quirk and Sykes 1971), topography (Rowe and Scotter 1973; Van Wagner 1983), changes in wind direction or speed, spatial location of humid, barren or rocky areas, water bodies and other landscape elements promoting fuels discontinuity across the landscape (Foster 1983; Eberhart and Woodard
1987). Islands can also be generated by spots that burn far from the fire perimeter and that eventually merge into the main burned area. In addition, long burning times increase fire intensity and wind direction variability (Foster 1983). Thus, small fires of short duration can be expected to have fewer islands and smaller unburned area. We found that the number of fire islands increased with fire size, as also reported by Eberhart and Woodard (1987). The spatial pattern of vegetation islands may play an important role in the success of the post-fire regeneration process and in the spread of subsequent fires.

Some vegetation types are more prone to burn. There is a rough gradient of fire occurrence along different vegetation types corresponding to a gradient from evergreen Mediterranean-type formations to temperate, deciduous forests. Particularly, fires were extensive in pine conifer forests and shrublands. In this region, shrublands are considered as early stages of succession. The dominant Pinus halepensis forests are also thought to develop in disturbed areas or as successional stages in abandoned agricultural lands (Folch 1996). Both types of plant communities develop under a Mediterranean-type climate. Evergreen, broad leaf forests grow on moister Mediterranean conditions and they burned less. This differential behaviour of tree species in front of fire supports fire prevention practices based in favouring broad leaf species in locations with high fire risk, particularly in populated areas. Finally, deciduous forests rarely burned. Although the Mediterranean-type communities of the region are largely resilient to fire and they can return to pre-disturbance conditions (Hanes 1971), fire regime and past land use may promote specific dynamics between these different types of vegetation (Lloret et al. 2002).

Most fires in Catalonia occur under the following conditions: altitude ranging from 250 to $750 \mathrm{~m}$, slope ranging from 10 to $60 \%$, mean annual temperature of $11-12{ }^{\circ} \mathrm{C}$, and mean annual rainfall ranging from 550 to $750 \mathrm{~mm}$. This altitude range fits areas with Mediterranean-type climate, except coastal areas and lowlands, which are densely populated or currently under agricultural use. Higher mountain ranges experience higher summer humidity and are less prone to burn. This pattern basically corresponds to the temperature and rainfall ranges. However, we found mean annual precipitation to be unrelated to fire occurrence. When water availability is too low, fuel availability for fire consumption also diminishes. This fact explains infrequent fires in low precipitation sites. In addition, 
fire occurrence mainly concentrates around a mean annual temperature (of $11-12^{\circ} \mathrm{C}$ ) where dense covered forestry concentrates (Catalonian Forest Inventory, Gracia et al. 1997). Topography also plays an important role in fire propagation, as largely considered in fire spread simulation models, such as FARSITE (Finney 1999). After ignition occurs, the fire front spread faster through steep slopes, also limiting the fire fighting tasks.

The expansion of protected areas in recent decades (144 reserves and parks covering $6000 \mathrm{~km}^{2}$, i.e., 20\% of Catalonia) has not been able to stop fires within them. An important part of these areas is covered by forests where fuel has being accumulated in the last decades. In addition, fire suppression efficiency may have been diminished by the absence of a maintained network of roads within these protected areas.

The comparison between the fractal dimension of patches of burned areas and forests suggests that fire shape fits the spatial pattern of available fuel for small patch sizes. This similarity of shape regularity declines at larger patch sizes, suggesting the importance of other fire drivers, such as meteorological conditions. Large fires should be mainly determined by extreme meteorological conditions, and by the own fire behaviour, because propagation sources exponentially increases with the size of the burning area. Fractal dimensions for both types of landscape patches are significantly different since main changes in $\mathrm{D}$ values occur at different patch sizes.

\section{Conclusion}

By analysing the spatial pattern of fire occurrence in a largely managed landscape, such as the western Mediterranean Basin, for the last decades of the $20^{\text {th }}$ century, we identify changes in the size distribution of burned areas. Active fire suppression policy has diminished the total number of fires, but it has not been able to decrease the contribution of large fires to the total burned area, which has resulted in an increase of the inequality between the size of burned areas.

The size of burned areas explains the occurrence pattern of burned spots and unburned vegetation islands within the fire perimeter. The larger the burned area, the more abundant are both types of fire-dependent landscape elements.

At a regional scale, fire occurrence is strongly linked to vegetation type. Shrublands and pine forests are more prone to burn than evergreen broad leaf forest, and particularly deciduous forest. This pattern is related to Mediterranean-type climate.

Finally, fire history reconstruction from burned area mapping allows spatial overlay with many other environmental layers by means of GIS. This tool enables ecological interpretation of both fire occurrence and fire behaviour, increasing the knowledge of forest fires, facilitating the improvement of fire management and post-fire conservation plans.

\section{Acknowledgements}

The authors want to express their gratitude to the Institut Cartogràfic de Catalunya for its help to process and correct geometrically the images, to the DMA and DARP (Generalitat de Catalunya) for the data provided about 1994-98 forest fire statistics. We want also to thank Andy Green for his help on English revision and 5 anonymous referees and the assigned editor who supplied very valuable comments on it. Financial support for this work came from the CICYT-MEC (AMB94-0881 and AGL2000-0678 projects), and a grant to $\mathrm{R}$. Díaz-Delgado by MEC. The study was also funded by the Lucifer EC project.

\section{References}

Agee J.K. 1993. Fire Ecology of Pacific Northwest Forests. Island Press, Washington DC, USA.

Albini F.A. 1976. Estimating wild fire behavior and effects. USDA Forest Service General Technical Report INT-30, Ogden, Utah, USA.

Arno S.F. and Sneck K.M. 1977. A method for determining fire history in coniferous forests of the mountain west. USDA Forest Service, Intermountain Forest and Range Experiment Station, General Technical Report INT-42, Ogden, Utah, USA.

Bendel R.B., Higgins S.S., Teberg J.E. and Pyke D.A. 1989. Comparison of skewness coefficient, coefficient of variation, and Gini coefficient as inequality measures within populations. Oecologia 78(3): 394-400.

CORINE 1991. Land-use land-cover database 1:250000. European Environment Agency, Copenhagen, Denmark.

DARP 1996. Mapa Forestal de Catalunya 1:100000. Departament d’Agricultura, Ramaderia i Pesca, Barcelona, España.

DARP 1999. FocVerd I. Programa de gestió del risc d’incendi forestal. Generalitat de Catalunya. Primersegona edicions, Barcelona, España, pp. 231.

Date C.J. 1995. An introduction to database systems. AddisonWesley Publishing Company, Reading, UK, pp. 839. 6 a edición.

Díaz-Delgado R., Lloret F. and Pons X. 2004. Temporal patterns of fire regime in Catalonia (NE of Spain) along the last quarter of century (1975-98). International Journal of Wildland Fire. 
Díaz-Delgado R., Lloret F. and Pons X. 2003. Influence of fire severity on plant regeneration by means of remote sensing imagery. International Journal of Remote Sensing 24: 1751-1763.

Díaz-Delgado R., Lloret F., Pons X. and Terradas J. 2002. Satellite evidence of decreasing resilience in Mediterranean plant communities after recurrent wildfires. Ecology 83: 2293-2303.

DMA 2001. Forests gestionades pel Departament de Medi Ambient, 1: 50000. Departament de Medi Ambient, Generalitat de Catalunya, Barcelona, España.

Donnegan J.A. and Rebertus A.J. 1999. Rates and mechanisms of subalpine forest succession along an environmental gradient. Ecology 80: 1370-1384.

Eberhart K.E. and Woodard P.M. 1987. Distribution of residual vegetation associated with large fires in Alberta. Canadian Journal of Forest Research 17: 1207-1212.

Finney M.A. 1999. Mechanistic modeling of landscape fire patterns.. In: Mladenoff D.J., Baker W.L. (eds), Spatial Modeling of Forest Landscapes: Approaches and Applications. Cambridge University Press, Cambridge, UK, pp. 186-209.

Folch R. 1986. La vegetació dels Països Catalans, Second edition. Ketres Editora S.A., Barcelona, España.

Folch R. 1996. Socioecologia dels incendis forestals. In: Terradas J. (ed.), Ecologia del Foc. Proa, Barcelona, España, pp. 255-261.

Foster D.R. 1983. The history and pattern of fire in the boreal forest of southeastern Labrador. Canadian Journal of Botany 61: 2459-2471.

Gasaway W.C. and DuBois S.D. 1985. Initial response of moose to a wildfire in interior Alaska. Canadian Field Naturalist 99: 135140.

Gracia C., Ibañez J.J., Vayreda J., Pons X. and Terradas J. 1997. Un nuevo concepto de inventario forestal. Proceedings of the XI world forestry congress. World Forestry Association, Antalya, Turkey, p. 43.

Hanes T.L. 1971. Succession after fire in the chaparral of Southern California. Ecological Monographs 41: 27-52.

Heinselman M.L. 1973. Fire in the virgin forests of the Boundary Waters Canoe Area, Minnesota. Quaternary Research 3: 329382.

ICC 1989. Mapa Geològic de Catalunya 1:250 000. Institut Cartogràfic de Catalunya, Barcelona, España.

ICC 1997. Atles Climàtic de Catalunya 1:500000. Institut Cartogràfic de Catalunya, Barcelona. 42 láminas.

ICC-DARP 1993. Modelo digital de elevaciones de Cataluña, 45 m. Institut Cartogràfic de Catalunya $\mathrm{y}$ Departament d’Agricultura, Ramaderia i Pesca, Barcelona, España. Edición digital.

Johnston C.A. 1990. GIS: more than just a pretty face. Landscape Ecology 4: 3-4.

Keeley J.E., Fotheringham C.J. and Morais M. 1999. Reexamining fire suppression impacts on brushland fire regimes. Science 284: 1829-1832.

Keeley J.E. and Fotheringham C.J. 2001. Historic fire regime in southern California shrublands. Conservation Biology 15: 1536-1548.

Kilgore B.M. and Taylor D. 1979. Fire history of a Sequoia-Mixed Conifer forest. Ecology 60: 129-142.

Krummel J.R., Gardner R.H., Sugihara G., O’Neill R.V. and Coleman P.R. 1987. Landscape patterns in a disturbed environment. Oikos 48: 321-324.
Lloret F., Calvo E., Pons X. and Díaz-Delgado R. 2002. Wildfires and landscape patterns of fragmentation in Eastern Iberian peninsula. Landscape Ecology 17: 745-759.

Lloret F., Pausas J.G. and Vila M. 2003. Responses of Mediterranean Plant Species to different fire frequencies in Garraf Natural Park (Catalonia, Spain): field observations and modelling predictions. Plant Ecology 167: 223-235.

Lee Ch. and Seyoung K., 1998. Measuring earnings inequality and median earnings in the tourism industry. Tourism Management 19: 341-348.

Lieffers V.J. and Titus S.J. 1989. The effects of stem density and nutrient status on size inequality and resource allocation in lodgepole pine and white spruce seedlings. Canadian Journal of Botany 67: 2900-2903.

Lorenz M.O. 1905. Methods of measuring concentration of wealth. J. Am. Stat. Assoc. 9: 209-219.

Lovejoy S. 1982. Area-perimeter relation for rain and cloud areas. Science 216: 185-187.

Maffini G. 1987. Raster versus vector data encoding and handling: a commentary. Photogrammetric Engineering and Remote Sensing 53: 1397-1398.

Malamud B.D., Morein G. and Turcotte D.L. 1998. Forest fires: an example of self-organized critical behavior. Science 281: 18401841.

Mandelbrot B.B. 1977. Fractals; form, chance and dimension. Freeman, San Francisco, California, USA, pp. 213.

MAPA 1979. Las coníferas en el primer inventario forestal nacional. Ministerio de Agricultura, Pesca y Alimentación, Madrid, España, pp. 174.

MAPA 1980a. Mapa de Cultivos y Aprovechamientos, 1:50000. Ministerio de Agricultura, Pesca y Alimentación, Madrid, España.

MAPA 1980b. Las frondosas en el primer inventario forestal nacional. Ministerio de Agricultura, Pesca y Alimentación, Madrid, España, pp. 235.

Miller C. and Urban D.L. 1999. Interactions between forest heterogeneity and surface fire regimes in the southern Sierra Nevada. Canadian Journal of Forest Research 29: 202-212.

Minnich R.A. and Chou Y.H. 1997. Wildland fire patch dynamics in the chaparral of Southern California and Northern Baja California. International Journal of Wildland Fire 7: 221-248.

Moreno J.M., Vázquez A. and Vélez R. 1998. Recent history of forest fires in Spain.. In: Moreno J.M. (ed.), Large Forest Fires. Backhuys Publishers, Leiden, The Netherlands, pp. 159-185.

Nikora V.I., Pearson C.P. and Shankar U. 1999. Scaling properties in landscape patterns: New Zealand experience. Landscape Ecology 14: 17-33.

Perry G.L.W., Sparrow A.D. and Owens I.F. 1999. A GIS-supported model for the simulation of the spatial structure of wildland fire, Cass Basin, New Zealand. Journal of Applied Ecology 36: 502518.

Piñol J., Terradas J. and Lloret F. 1998. Climate warming, wildfire hazard, and wildfire occurrence in coastal eastern España. Climatic Change 38: 345-357.

Pons X. 1996. Estimación de la radiación solar a partir de modelos digitales de elevaciones: Propuesta metodológica.. In: Juaristi y I. Moro J. (ed.), Modelos y Sistemas de Información en Geografía. UPV-AGE, Vitoria, pp. 87-97.

Quirk W.A. and Sykes D.J. 1971. White spruce stringers in a firepatterned landscape in interior Alaska.. In: Slaughter C.W., Barney R.J. and Hansen G.M. (eds), Fire in the Northern 
Environment. A symposium. USDA Forest Service, Pacific Northwest Forest and Range Experiment Station, Portland, Oregon, USA, pp. 179-197.

Reed W.J. and McKelvey K.S. 2002. Power-law behaviour and parametric models for the size-distribution of forest fires. Ecological Modelling 150: 239-254.

Ricotta C., Avena G. and Marchetti M. 1999. The flaming sandpile:self-organized criticality and wildfires. Ecological Modelling 119: 73-77.

Ricotta C., Arianoutsou M., Díaz-Delgado R., Duguy B., Lloret F., Maroudi E., Mazzoleni S., Moreno J.M., Rambal S., Vallejo R. and Vázquez A. 2001. Self-Organized Criticality of Wildfires Ecologically Revisited. Ecological Modelling 141: 307-311.

Rothermel R.C. 1972. A mathematical model for predicting fire spread in wildland fuels. USDA Forest Service Research Papers INT-115, Ogden, Utah, USA.

Rothermel R.C. 1983. How to predict the spread and intensity of forest and range fires. USDA Forest Service Technical Report INT-143, Ogden, Utah, USA.

Rowe J.S. and Scotter G.W. 1973. Fire in the boreal forest. Quaternary Research 3: 444-464.

Rousseau R., Van Hecke P., Nijssen D. and Bogaert J. 1999. The relationship between diversity profiles, evenness and species richness based on partial ordering. Environmental and Ecological Statistics 6: 211-223.

Salvador R., Valeriano J., Pons X. and Díaz-Delgado R. 2000. A semiautomatic methodology to detect fire scars in shrubs and evergreen forests with Landsat MSS time series. International Journal of Remote Sensing 21: 655-673.

Strauss D., Bednar L. and Mees R. 1989. Do one percent of forest fires cause ninety-nine percent of the damage? Forest Science 35: 319-328.
Terradas J. and Piñol J. 1996. Els grans incendis: condicions meteorològiques i de vegetació per al seu desenvolupament. In: Terradas J. (ed.), Ecologia del Foc. Proa, Barcelona, España, pp. 63-75.

Trabaud L. 1992. Les feux de forêt. France selection, Paris, France, pp. 278.

Trabaud L. 1994. Post-fire plant community dynamics in the Mediterranean Basin.. In: Moreno J.M. and Oechel W.C. (eds), The role of fire in Mediterranean-type ecosystems. Ecological Studies, Springer, pp. 1-15.

Van Wagner C.E. 1983. Fire behavior in northern conifer forests and shrublands. In: Wein R.W. and MacLean D.A. (eds), The role of fire in northern circumpolar ecosystems. John Wiley and Sons, New York, USA, pp. 65-80.

Weiner J. and Thomas S.C. 1986. Size variability and competition in plant monocultures. Oikos 47: 211-222.

Wells M.L. and McKinsey D.E. 1990. Using a geographic information system for prescribed fire management at Cuyamaca Rancho State Park, California. In: Proceedings of the GIS'90 Symposium. GIS'90, Los Angeles, USA, pp. 87-93.

Whelan R.J. 1995. The ecology of fire. Cambridge University Press, Cambridge, UK.

Zedler P.H., Gautier C.R. and McMaster S. 1983. Vegetation change in response to extreme events: the effect of short interval between fires in California chaparral and coastal scrub. Ecology 64: 809-818.

Zasada J.C. 1971. Natural regeneration of interior Alaska forests. Seed, seedbed and vegetative reproduction considerations. In: Slaughter C.W., Barney R.J. and Hansen G.M. (eds), Fire in the Northern Environment: A Symposium. USDA Forest Service, Portland, USA, pp. 231-246. 